\title{
Investigation of emissions characteristics of secondary butyl alcohol-gasoline blends in a port fuel injection spark ignition engine
}

\author{
I.M. Yusri ${ }^{1, *}$, Rizalman Mamat ${ }^{1,2}$, A. Aziz ${ }^{1,2}$, A.F. Yusop ${ }^{1,2}$, Omar I. Awad ${ }^{1}$ and S.M. Rosdi ${ }^{1}$ \\ ${ }^{1}$ Faculty of Mechanical Engineering, Universiti Malaysia Pahang (UMP), 26600 Pekan, Pahang, \\ Malaysia \\ ${ }^{2}$ Automotive Engineering Centre, Universiti Malaysia Pahang (UMP), 26600 Pekan, Pahang, \\ Malaysia
}

\begin{abstract}
Exhaust emissions especially from light duty gasoline engine are a major contributor to air pollution due to the large number of vehicles on the road. The purpose of this study is to experimentally analyse the exhaust pollutant emissions of a four-stroke port fuel spark ignition engines operating using secondary butyl alcohol-gasoline blends by percentage volume of 5\% (GBu5), 10\% (GBu10) and 15\% (GBu15) of secondary butyl- alcohol (2-butanol) additives in gasoline fuels at $50 \%$ of wide throttle open. The exhaust emissions characteristics of the engine using blended fuels was compared to the exhaust emissions of the engine with gasoline fuels $(\mathrm{G} 100)$ as a reference fuels. Exhaust emissions analysis results show that all of the blended fuels produced lower $\mathrm{CO}$ by $8.6 \%$, $11.6 \%$ and $24.8 \%$ for GBu5, GBu10 and GBu15 respectively from 2500 to $4000 \mathrm{RPM}$, while for $\mathrm{HC}$, both GBu10 and GBu15 were lower than that G100 fuels at all engine speeds. In general, when the engine was operated using blended fuels, the engine produced lower $\mathrm{CO}$ and $\mathrm{HC}$, but higher $\mathrm{CO}_{2}$.
\end{abstract}

\section{Introduction}

Climatic change of the earth have triggered a global warning to each corner of this earth due to its adverse effects to each living creatures. Based on the estimation done by International Energy Agency (IEA), a rose by 53\% in global energy consumption is foreseen by the year of 2030 [1]. Malaysia alone estimated to have an increment of gross domestic product (GDP) by $4.6 \%$ in between 2004 to 2030, which indicate that increased of GDP by $1 \%$ approximately resulted to growth of energy demand by $1 \%$ [2]. Transportation sector are one of the major contributor in rise of energy demand mainly from gasoline and diesel engine vehicles which consumed depleted fossilized fuels [3-5]. Perhaps one of the potential solution that could possibly bring back the balanced in energy consumption and the climatic change in this world is by introducing the biofuel in the transportation areas[67].

* Corresponding author: yusri890@yahoo.com 
The use of alternative clean biofuels such as methanol, ethanol and butanol is one of the method to reduce the dependency on the energy demand for fossilized fuels in spark ignition engine [8-10]. However for the past few years the investigation of methanol and ethanol have received considerable critical attention with less attention paid to the butanol as a sustainable fuel substitutions alternative. Basically butanol is a four carbon chain of alcohol types. It exist in four types of isomers; 1-butanol, 2-butanol, tert-butanol and isobutanol. Each types of isomer have different physicochemical properties. Butanol are considered as an advanced biofuel due to its superior characteristics compared to other alcohol family members [11-13]. Compared to methanol and ethanol butanol have the nearest fuel properties similarity to the gasoline fuel such as stoichiometric air fuel ratio, latent heating value, energy content, octane number and auto ignition temperature thus make it more suitable to be blended with gasoline fuel [14-16]. Furthermore butanol can be transported through the existing fuel pipeline as it is less corrosion. With all of the advantages offered by butanol without doubt it has been proposed as a next generation biofuel as an alternative to the conventional fuels [17-18].

Taking this into account, n-butanol undoubtedly to have a very remarkable prospective because its properties are almost similar to gasoline fuels. This can reduce the efforts that to be done to adapt their current range of vehicles to be able to run on butanol-gasoline blends. Various precious study has been done to investigate the butanol additive in a gasoline fuels. Among the recent study are from Feng et al. [19]. They used to investigate the effects of adding butanol additives by $30 \%$ and $35 \%$ of percentage volume in a gasoline fuels using single cylinder spark ignition (SI) engine. Based on his heat release analysis, butanol addition indicates higher knocking resistance. Szwaja and Naber [20] reported that the early combustion duration and length of combustion duration in a SI engine were shortened with increased of n-butanol volumes. In another study shorter early combustion duration stage, better combustion stability and faster combustion was stated by other researchers [21-22].

Galloni et al. [23] studied the effect of butanol and its blends by $(20 \%$ and $40 \%$ of butanol volume) on engine performance and emissions by using port fuel injected turbocharged SI engine. The author found that the engine torque and thermal efficiency drop by approximately $4 \%$ for butanol-gasoline blends compared to the gasoline fuels. Singh et al. [24] conducted an experimental study on $5 \%, 10 \%, 20 \%, 50 \%$ and $75 \%$ of butanol volume percentage in a gasoline fuels with medium duty transportation SI engine. They found that reduction of brake thermal efficiency (BTE) and exhaust gas temperature, brake specific nitrogen oxides (BSNO), brake specific carbon monoxides (BSCO) and smoke emissions for butanol-gasoline blends compared to the pure gasoline fuels. Elfasakhany [25] analyzed the effects of performance and emissions of an engine fueled with low proportion of n-butanol by $0,3,7$ and $10 \%$ volume $n$-butanol-gasoline blends. Experimental investigation have been done without any modifications on the SI engine systems. Based on the results show that engine in-cylinder pressure, torque, and exhaust gas temperature of the engine slightly decrease when n-butanol-gasoline blended fuels are used. Moreover blended fuel also produced lower $\mathrm{CO}, \mathrm{CO}_{2}$ and $\mathrm{HC}$ concentrations compared to those of neat gasoline. Yacoub et al. [26] examined butanol-gasoline blends with carbon numbers $\mathrm{C} 1$ to $\mathrm{C} 5$. The results showed that all n-butanol blends had lower $\mathrm{CO}$ and UHC emissions. Alasfour [27-28] evaluated the effect of using 30\% n-butanol by volume blended with gasoline in a single-cylinder SI engine. He found that the lower engine efficiency by $7 \%$ compared to pure gasoline fuel.

This study aim to integrate the existing experimental investigation on combustion performance and emissions characteristics of a SI engine fueled with butanol-gasoline blends in a low proportion of butanol mixture by $5 \%, 10 \%$ and $15 \%$ at $50 \%$ of wide throttle open (WTO) varied from 1000 to 4000 RPM with interval of 500 RPM. Butanol used in 
this study are from the second butanol family namely secondary butyl alcohol (secbutanol). This research can contribute to further the knowledge on the effects of butanol mixture in a four cylinder four strokes port fuel injection SI engines. In addition, as far as the author concern there are little attention has been paid to butanol-gasoline blends mixture from the secondary butyl alcohol family. The investigation of emissions characteristics analyses were performed; in particular $\mathrm{CO}, \mathrm{CO}_{2}$, and $\mathrm{HC}$.

\section{Experimental setup}

\subsection{Materials}

In this research investigation, engine testing was done with gasoline fuels as a reference fuels (G100) and blends of 5\%,10\% and $15 \%$ by volume of sec-butanol in a gasoline fuels indicated as GBu5, GBu10 and GBu15 respectively. Briefly, 2-butanol was added into gasoline fuels and mixed at low stirring rate using an electric magnetic. The mixture was stirred continuously for 15 minutes at room temperature to prepare the blended fuels. Gasoline fuels was bought from local petrol station and stored in the lab inside the proper container. The 2-butanol with percentage of purity of $99.5 \%$ were bought from Merck distributor in Malaysia as in Figure 1. The properties of G100 and 2-butanol fuels are specified in Table 1. The fuel blends were prepared just before the start of experiment to ensure that the fuel mixture was homogenous.

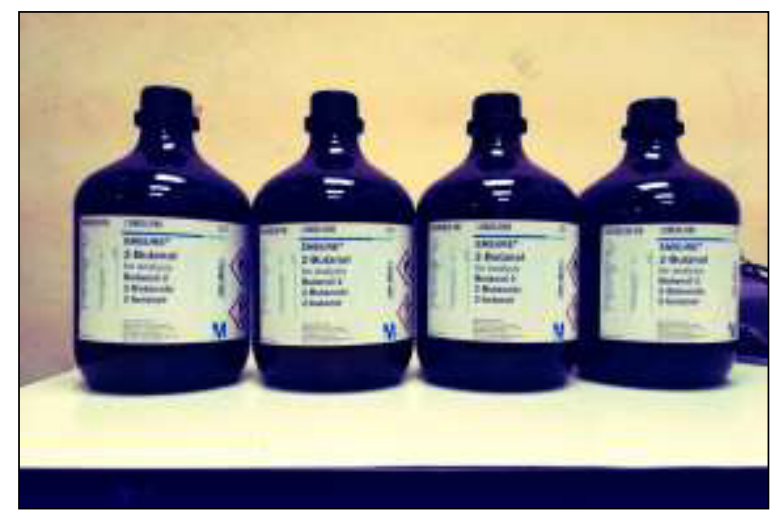

Fig 1. 2-butanol purchased through Merck distributor in Malaysia

\subsection{Experimental procedure}

In this experimental study, the experiments were performed on a Mitsubishi 1.8 single overhead camshaft (SOHC) engines with four cylinders, four stroke and spark ignition engines. The engine specifications are specified in Table 2. Figure. $2 \mathrm{a}$ and $\mathrm{b}$ present the actual engine and schematic diagram of the engine experimental test setup. A $100 \mathrm{~kW}$ of Dynalec Controls eddy current dynamometer was fixed to the engine in order to apply a consistent $50 \%$ of WTO conditions. The load exerted on the engine is measured by the load cell connected to the eddy current dynamometer. All the experiments are conducted and the results are recorded under steady state conditions. Fuel consumption was occupied using AIC fuel flow rate meter with an accuracy of $1 \%$ reading. Air consumption was recorded using Benetech GM8903 hot wire type anemometer with the air speeds resolution by 0.001 $\mathrm{m} / \mathrm{s}$. The relative air fuel ratio was measured using an accurate calibrated KANE gas 
analyzer version autoplus 5-2. Sensitivity and measurements accuracy of the exhaust gas concentration have been described in Table 3 .

Table 1. Properties of gasoline and 2-butanol [11,21,29-30].

\begin{tabular}{|l|l|l|}
\hline \multicolumn{1}{|c|}{ Property } & \multicolumn{1}{|c|}{ Gasoline } & \multicolumn{1}{|c|}{ 2-butanol } \\
\hline Molar C/H ratio & $0.44-0.50$ & - \\
\hline Density $\left(\mathrm{kg} / \mathrm{m}^{3}\right)$ & 736 & 806.3 \\
\hline $\begin{array}{l}\text { Latent heating value } \\
(\mathrm{kJ} / \mathrm{kg})\end{array}$ & 44,300 & 33,000 \\
\hline $\begin{array}{l}\text { Stoichiometric air/fuel } \\
\text { ratio }\end{array}$ & 14.6 & 11.1 \\
\hline RON/MON & $95 / 85$ & $101 / 92 \sim 97$ \\
\hline $\begin{array}{l}\text { Auto - ignition } \\
\text { temperature }\left({ }^{\circ} \mathrm{C}\right)\end{array}$ & $228-470$ & 406.1 \\
\hline Boiling point $\left({ }^{\circ} \mathrm{C}\right)$ & $27-225$ & 99.5 \\
\hline $\begin{array}{l}\text { Heat of vaporization } \\
\text { (kJ/kg) }\end{array}$ & 349 & 551 \\
\hline $\begin{array}{l}\text { Flammable limits } \\
(\% \text { volume })\end{array}$ & $1.4-7.6$ & $1.7-9.8$ \\
\hline Laminar flame speeds $[31]$ & $\sim 33$ & $\sim 48$ \\
\hline
\end{tabular}

Table 2. Engine specifications.

\begin{tabular}{|l|l|}
\hline \multicolumn{2}{|l|}{ Engine descriptions } \\
\hline Bore x Stroke & $81.0 \mathrm{~mm} \times$ x 89.0mm \\
\hline Piston displacement & $1834 \mathrm{cc}$ \\
\hline Compression ratio & $9.5: 1$ \\
\hline Fuel injection type & $\begin{array}{l}\text { ECI-Multi (Electronically Controlled } \\
\text { Multi-point Fuel Injection }\end{array}$ \\
\hline Max power & $86 \mathrm{~kW} @ 5500 \mathrm{rpm}$ \\
\hline Max torque & $161 \mathrm{Nm} @$ 4500rpm \\
\hline
\end{tabular}

Table 3. Sensitivity and measurements accuracy of instruments used for measuring the exhaust gas concentration.

\begin{tabular}{|l|l|l|}
\hline Exhaust gas & Measurements domain & Measurement accuracy \\
\hline $\mathrm{CO}$ & $0-21 \%$ & $+/-5 \%$ or $0.06 \%$ volume \\
\hline $\mathrm{CO}_{2}$ & $0-16 \%$ & $+/ 5 \%$ or $0.5 \%$ volume \\
\hline $\mathrm{HC}$ & $0-5000 \mathrm{ppm}$ & $+/-5 \%$ or $12 \mathrm{ppm}$ volume \\
\hline
\end{tabular}




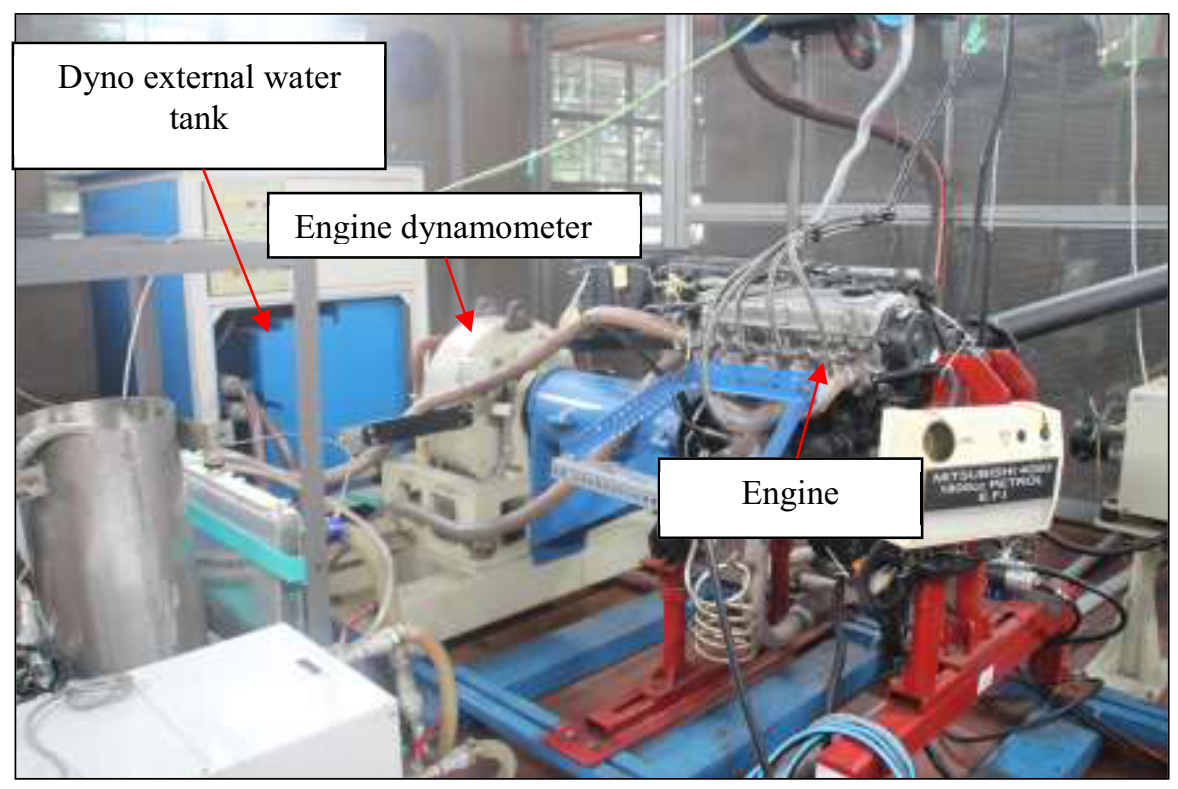

(a)

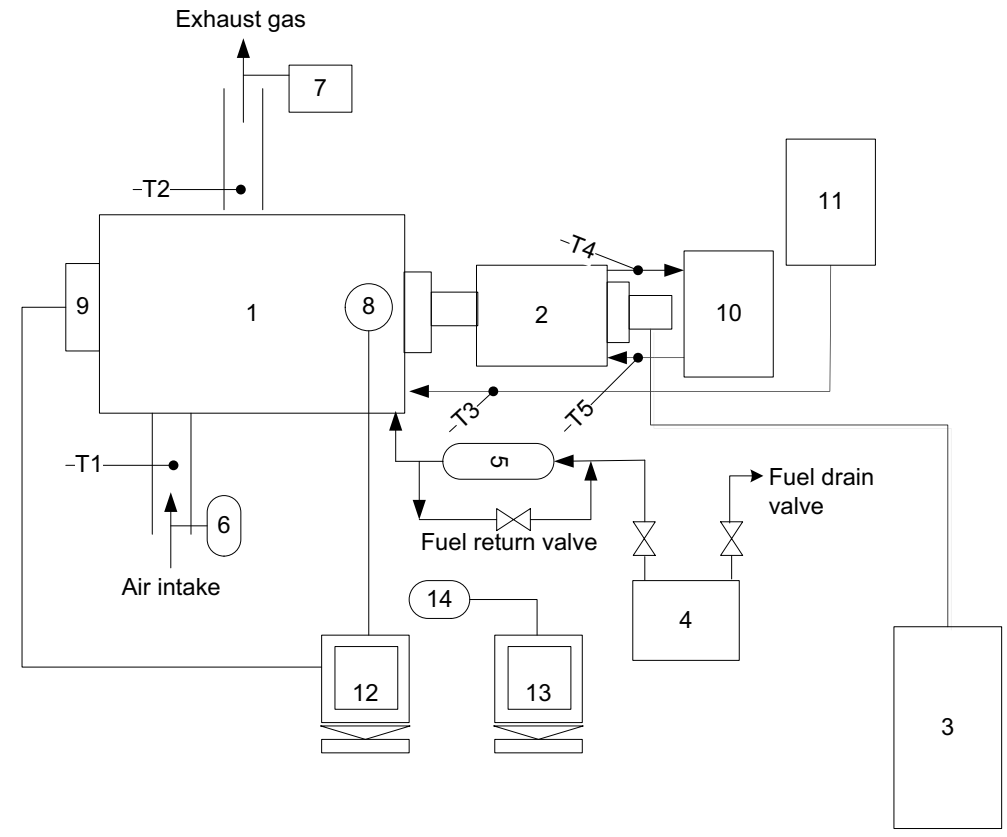

(b)

Fig 2. Engine test bed and test instruments (a) actual and (b) schematic
1. Engine test setup
8. In-cylinder pressure sensor
2. Eddy current dynamometer
9. Kistler crank encoder
3. Dyno controller
10. Dyno external water tank
4. Fuel tank
11. Engine external water tank
5. Fuel pump
12. Dewe-5000 combustion analyzer
6. Air flow rate
13. Computer
7. Exhaust gas analyzer
14. Data logger 


\subsection{Emissions index}

The emissions data were reported using emission index basis to allow comparisons to be made between the different sizes of engines and fuel chemical compositions. According to Saxena and Jotshi [32], the emissions index (EI) can be calculated using the following equations:

$$
E I_{i}=\left(\frac{X_{i}}{X_{C O}+X_{C O_{2}}+X_{H C}}\right)\left(\frac{\chi M V_{i}}{M W_{f}}\right)
$$

Where it can be simplified as:

$$
\begin{aligned}
& E I_{C O}=\left(\frac{C O}{C O+C O_{2}+H C}\right) \times 100 \% \\
& E I_{C_{2}}=\left(\frac{C O_{2}}{C O+C O_{2}+H C}\right) \times 100 \% \\
& E I_{H C}=\left(\frac{H C}{C O+C O_{2}+H C}\right) \times 100 \%
\end{aligned}
$$

Where $\mathrm{CO}, \mathrm{CO}_{2}$ and $\mathrm{HC}$ are in parts per million (PPM).

\section{Results and discussions}

In this study, the sec-butanol-gasoline blended fuels are examined in three different proportions $(5 \%, 10 \%$ and $15 \%)$ and are compared to the reference fuels neat gasoline fuels in terms of emissions characteristics. The quantity of GBuX represents a blend consisting of $\mathrm{X} \%$ of sec-butanol by percentage of volume, e.g., GBu5 indicates a blend consisting of $5 \%$ of 2-butanol in $95 \%$ of gasoline. Four test fuels were used in this study: gasoline (G100); 5\% of 2-butanol (GBu5); 10\% of butanol (GBu10); and 15\% of (GBu15). Incomplete combustion and poor mixing of air and fuel are the major causes of $\mathrm{CO}$ productions [33].In Figure 3 presents effects of sec-butanol additions in gasoline fuels to the carbon monoxides (CO) emissions index (EI). From Figure 3, a slight increase was observed for blended fuels from engine speeds 1000 to 2500 RPM. However, as the engine speeds achieved engine speeds of 2500 to 4000 RPM, G100 fuels produced higher CO emissions as compared to blended fuels. The average reduction of $\mathrm{CO}$ emissions was calculated for blended fuels compared to G100 fuels in order to distinguish the effects of sec-butanol addition in G100 fuels. A significant of reduction by average of $8.6 \%, 11.6 \%$ and $24.8 \%$ for GBu5, GBu10 and GBu15 respectively throughout the speed range of 2500 to 4000 RPM. Hence, the blended fuels is more combustible than the G100 fuels. It appears that this result is in accordance with the studies which have already been reported such as in Ref. [21,34]. 


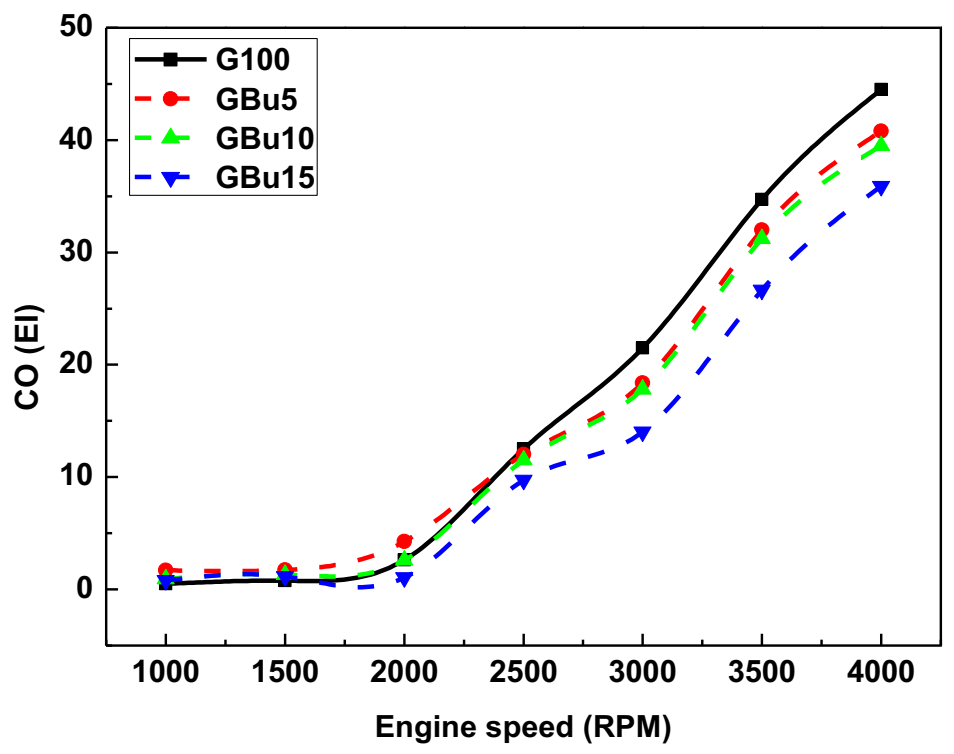

Fig 3. Emission index of carbon monoxide at $50 \%$ of WTO

Figure 4 shows effects of sec-butanol additions in a gasoline fuels to the carbon dioxides $\left(\mathrm{CO}_{2}\right)$. The $\mathrm{CO}_{2}$ EI of the $\mathrm{G} 100$ was found to be lower than that blended fuels throughout the engine speed of 25004000 RPM and on the average it was around $3.7 \%$, $4.7 \%$ and $9.1 \%$ lower than that of the GBu5, GBu10 and GBu15 respectively. Such increasing trends in the $\mathrm{CO}_{2}$ EI for the blended fuels may refer to oxygen contents in the sec-butanol. Based on the chemical composition, gasoline only contains carbon and hydrogen atoms; however sec-butanol contains excess oxygen contents including carbon and hydrogen atom. Accordingly, it is realistic to get such $\mathrm{CO}_{2}$ EI enlargement at using blended fuels.

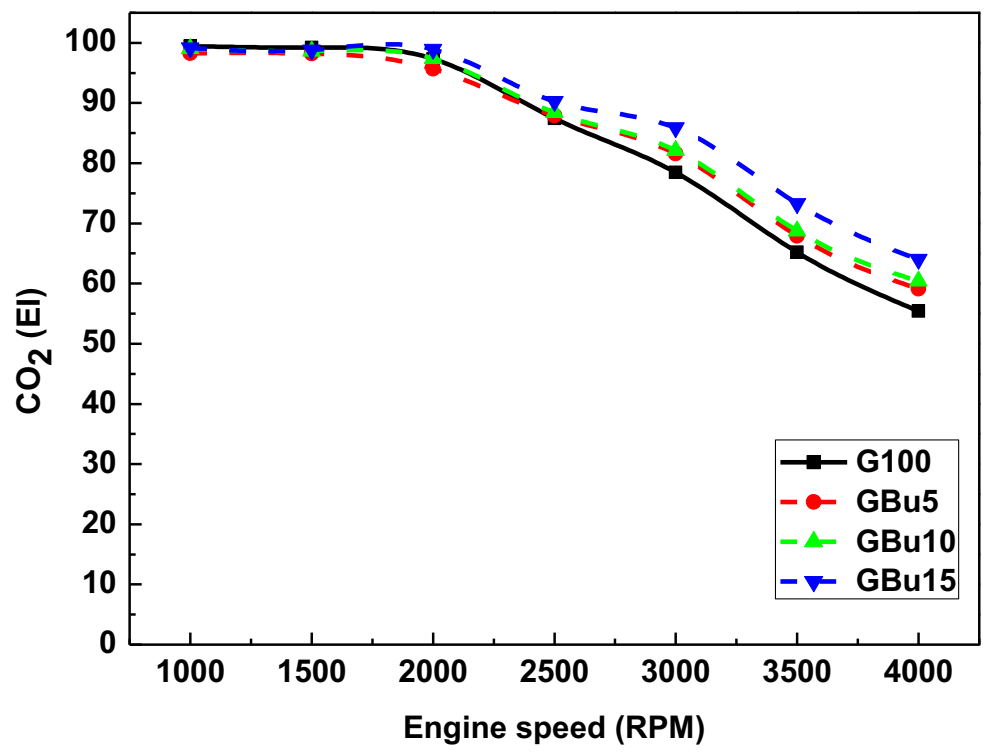

Fig 4. Emission index of carbon dioxide at $50 \%$ of WTO 
Figure 5 indicates the experimental results on effects of sec-butanol additions in a gasoline fuels to the unburned hydrocarbon (HC). Strong evidence of $\mathrm{HC}$ reductions was found especially for $10 \%$ and $15 \%$ by volume of sec-butanol additions in gasoline fuels. However, comparing the two results between G100 and GBu5, it can be seen that the EI of GBu5 from engine speed 1000 to 2500 RPM was higher than G100 fuels. The rate of HC release is mainly influenced by the chemical compositions of carbon, hydrogen and oxygen of the respective fuels. In a four stroke engine process, particularly in expansion process, drop in cylinder draws compressed unburnt fuel from crevice volume to create unreacted fuel particle that remains in the exhaust. The unreacted unburned fuel continues to increase as the combustion process of the engine continues. The molecular weight of gasoline (114) is much higher than sec-butanol (74.1). Mixture of sec-butanol-gasoline blends produce lower molecular weight of blended fuel. Being a much more light weight fuel sec-butanolgasoline blends capable to form much better homogenous air-fuel mixture. In addition, presence of oxygen further improve the combustion of the blended fuels. From the calculation, the HC EI of GBu10 and GBu15 was lower than that of the G100 throughout the engine speed range, and on average of $13.4 \%$ and $27.1 \%$ for GBu10 and GBu15 respectively.

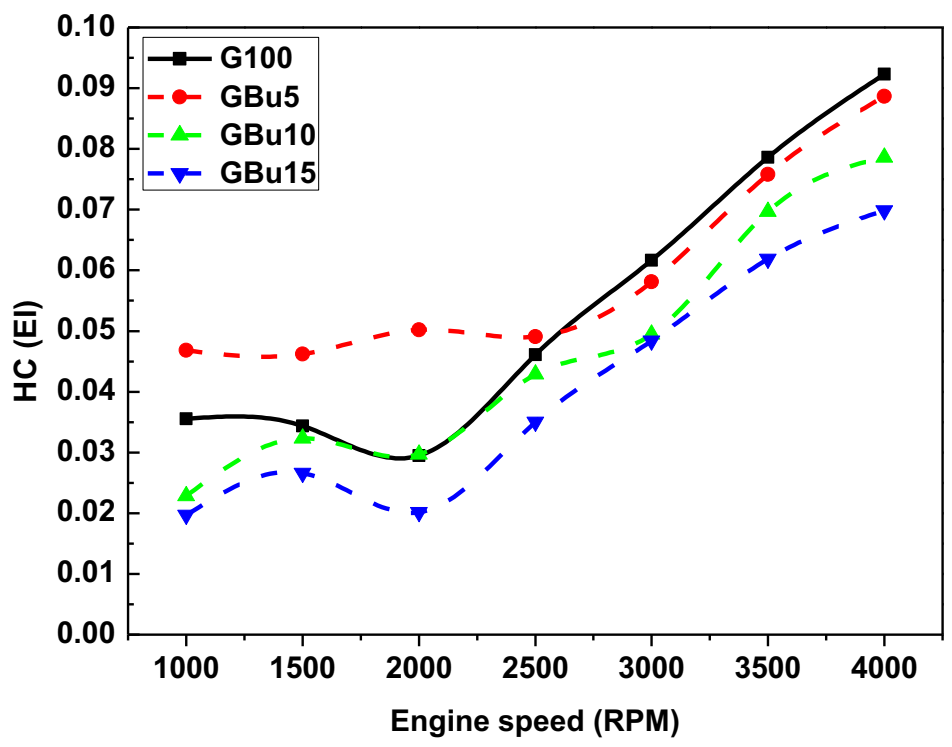

Fig 5. Emission index of unburned hydrocarbon at $50 \%$ of WTO

\section{Conclusions}

From this research investigation, it can be concluded that 2-butanol gasoline blends of GBu5, GBu10 and GBu15 can be directly used in gasoline engines without modifications. The evidence from this experimental study suggests that throughout the engine speeds of 1000 to 2500 RPM GBu5 produces higher $\mathrm{CO}$ and $\mathrm{HC}$, but lower CO2 EI compared to the G100 fuels. On the other hand, following the increase of engine speeds from 2500 to 4000 RPM, all of the blended fuels significantly reduced CO by percentage average of $8.6 \%$, $11.6 \%$ and $24.8 \%$ for GBu5, GBu10 and GBu15 respectively. Meanwhile G100 fuels produced lower $\mathrm{CO} \neg 2$ by averaged of $3.7 \%, 4.7 \%$ and $9.1 \%$ lower than that of the GBu5, GBu10 and GBu15 respectively. It is also worth noting that HC EI deteriorated by averaged of $13.4 \%$ and $27.1 \%$ for GBu10 and GBu15 respectively compared to the G100 fuels throughout all engine speeds. 
Appreciation and acknowledgement to the Ministry of Higher Education (KPT) for providing author the scholarship under My Brain 15 schemes and financial support under Universiti Malaysia Pahang Grand RDU 1403156. Sincere thanks to Mr. Muhd Hafietz Bin Yusoff for bountiful assistant in term of technical supports during the engine testing. Finally, the authors thank the anonymous referees and the editor for carefully reading this paper and suggesting many helpful comments on improving the original manuscript.

\section{References}

1 H. C. Ong, T. M. I. Mahlia and H. H. Masjuki. (2012). A review on energy pattern and policy for transportation sector in Malaysia. Renewable and Sustainable Energy Reviews, 16(1), 532-542.

2 A. Fazeli, F. Bakhtvar, L. Jahanshaloo, N. A. Che Sidik and A. E. Bayat. (2016). Malaysia's stand on municipal solid waste conversion to energy: A review. Renewable and Sustainable Energy Reviews, 58, 1007-1016.

3 Y. F. Wang, K. P. Li, X. M. Xu and Y. R. Zhang. (2014). Transport energy consumption and saving in China. Renewable and Sustainable Energy Reviews, 29, 641-655.

4 Y. S. H. Najjar. (2013). Protection of the environment by using innovative greening technologies in land transport. Renewable and Sustainable Energy Reviews, 26, 480491.

5 S. A. Osman, A. J. Alimin, M. Y. Ismail and K. W. Hui. (2013). Performance and Emission Characteristics of Direct Injection C.I Engine Retrofitted with Mono-CNG System. Applied Mechanics and Materials, 446-447, 443-447.

6 B. L. Salvi, K. A. Subramanian and N. L. Panwar. (2013). Alternative fuels for transportation vehicles: A technical review. Renewable and Sustainable Energy Reviews, 25, 404-419.

7 B. L. Salvi and N. L. Panwar. (2012). Biodiesel resources and production technologies - A review. Renewable and Sustainable Energy Reviews, 16(6), 3680-3689.

8 B. M. Masum, H. H. Masjuki, M. A. Kalam, S. M. Palash, M. A. Wakil and S. Imtenan. (2014). Tailoring the key fuel properties using different alcohols (C2-C6) and their evaluation in gasoline engine. Energy Conversion and Management, 88, 382390.

9 B. M. Masum, H. H. Masjuki, M. A. Kalam, S. M. Palash and M. Habibullah. (2015). Effect of alcohol-gasoline blends optimization on fuel properties, performance and emissions of a SI engine. Journal of Cleaner Production, 86, 230-237.

10 A. Elfasakhany. (2015). Investigations on the effects of ethanol-methanol-gasoline blends in a spark-ignition engine: Performance and emissions analysis. Engineering Science and Technology, an International Journal, 18(4), 713-719.

11 C. Jin, M. Yao, H. Liu, C.-f. F. Lee and J. Ji. (2011). Progress in the production and application of n-butanol as a biofuel. Renewable and Sustainable Energy Reviews, 15(8), 4080-4106.

12 I. M. Yusri, M. K. Akasyah, R. Mamat and O. M. Ali. (2015). Combustion and emissions characteristics of a compression ignition engine fuelled with n-butanol blends. Jurnal Teknologi (Science and Engineering), 77(8), 69-73.

13 I. M. Yusri, R. Mamat, O. M. Ali, A. Aziz, M. Akasyah, M. K. Kamarulzaman, et al. (2016). The combustion of n-butanol-diesel fuel blends and its cycle to cycle variability in a modern common-rail diesel engine. Journal of Engineering and Applied Sciences, 11(4), 2297-2301. 
14 A. Irimescu. (2012). Performance and fuel conversion efficiency of a spark ignition engine fueled with iso-butanol. Applied Energy, 96, 477-483.

15 Z. Chen, Z. Wu, J. Liu and C. Lee. (2014). Combustion and emissions characteristics of high n-butanol/diesel ratio blend in a heavy-duty diesel engine and EGR impact. Energy Conversion and Management, 78, 787-795.

16 A. Uyumaz. (2015). An experimental investigation into combustion and performance characteristics of an HCCI gasoline engine fueled with n-heptane, isopropanol and nbutanol fuel blends at different inlet air temperatures. Energy Conversion and Management, 98, 199-207.

17 E. G. Giakoumis, C. D. Rakopoulos, A. M. Dimaratos and D. C. Rakopoulos. (2013). Exhaust emissions with ethanol or n-butanol diesel fuel blends during transient operation: A review. Renewable and Sustainable Energy Reviews, 17, 170-190.

18 A. Demirbas. (2008). Biofuels sources, biofuel policy, biofuel economy and global biofuel projections. Energy Conversion and Management, 49(8), 2106-2116.

19 R. Feng, J. Fu, J. Yang, Y. Wang, Y. Li, B. Deng, et al. (2015). Combustion and emissions study on motorcycle engine fueled with butanol-gasoline blend. Renewable Energy, 81, 113-122.

20 S. Szwaja and J. D. Naber. (2010). Combustion of n-butanol in a spark-ignition IC engine. Fuel, 89(7), 1573-1582.

21 X. Gu, Z. Huang, J. Cai, J. Gong, X. Wu and C.-f. Lee. (2012). Emission characteristics of a spark-ignition engine fuelled with gasoline-n-butanol blends in combination with EGR. Fuel, 93, 611-617.

22 J. Dernotte, C. Mounaim-Rousselle, F. Halter and P. Seers. (2009). Evaluation of butanol-gasoline blends in a port fuel-injection, spark-ignition engine. Oil \& Gas Science and Technology - Revue de l'Institut Français du Pétrole, 65(2), 345-351.

23 E. Galloni, G. Fontana, S. Staccone and F. Scala. (2016). Performance analyses of a spark-ignition engine firing with gasoline-butanol blends at partial load operation. Energy Conversion and Management, 110, 319-326.

24 S. B. Singh, A. Dhar and A. K. Agarwal. (2015). Technical feasibility study of butanol-gasoline blends for powering medium-duty transportation spark ignition engine. Renewable Energy, 76, 706-716.

25 A. Elfasakhany. (2014). Experimental study on emissions and performance of an internal combustion engine fueled with gasoline and gasoline/n-butanol blends. Energy Conversion and Management, 88, 277-283.

26 Y. Yacoub, R. Bata and M. Gautam. (1998). The performance and emissions characteristics of $\mathrm{C} 1-\mathrm{C} 5$ alcohol-gasoline blends with matched oxygen content in a single-cylinder spark igntion engine. Proceedings of the Institution of Mechanical Engineers, Part A: Journal of Power and Energy, 212.

27 F. N. Alasfour. (1997). Butanol - A single-engine study: Availability analysis. Applied Thermal Engineering, 17(6), 537-549.

28 F. Alasfour. (1999). The effect of using 30\% iso-butanol-gasoline blend on hydrocarbon emissions from a spark-ignition engine. Energy Sources, 21(5), 379-394.

29 M. K. Balki and C. Sayin. (2014). The effect of compression ratio on the performance, emissions and combustion of an SI (spark ignition) engine fueled with pure ethanol, methanol and unleaded gasoline. Energy, 71, 194-201.

30 E. Christensen, J. Yanowitz, M. Ratcliff and R. L. McCormick. (2011). Renewable oxygenate blending effects on gasoline properties. Energy \& Fuels, 25(10), 4723-4733.

31 K. Nithyanandan, H. Wu, M. Huo and C.-F. Lee. (; 2014). A preliminary investigation of the performance and emissions of a port-fuel Injected SI engine fueled with acetonebutanol-ethanol (ABE) and gasoline. SAE technical paper 2014-04-01. 
32 S. Saxena and C. Jotshi. (1994). Fluidized-bed incineration of waste materials. Progress in Energy and combustion Science, 20(4), 281-324.

33 M. I. Jahirul, H. Masjuki, R. Saidur, M. Kalam, M. Jayed and M. Wazed. (2010). Comparative engine performance and emission analysis of CNG and gasoline in a retrofitted car engine. Applied Thermal Engineering, 30(14), 2219-2226.

34 G. Broustail, F. Halter, P. Seers, G. Moréac and C. Mounaim-Rousselle. (2012). Comparison of regulated and non-regulated pollutants with iso-octane/butanol and isooctane/ethanol blends in a port-fuel injection spark-ignition engine. Fuel, 94, 251-261. 